\title{
Evaluation of suitability of Windhoek's wastewater effluent for re-use in vegetable irrigation: a case study of Gammams effluent
}

\author{
L. G. Moyo, A. Vushe, M. A. January \& D. A. Mashauri \\ Department of Civil and Environmental Engineering, \\ Polytechnic of Namibia, Namibia
}

\begin{abstract}
Reuse of wastewater for vegetable irrigation may provide the nutrients required for crop growth while reducing the potential deterioration of receiving water bodies due to eutrophication. Evaluation of the suitability of treated effluent for use in vegetable irrigation was done by measuring the physical, chemical and bacteriological quality of the effluent. The effluent water samples were collected along the streams from the wastewater treatment plant at the point of irrigation water abstraction. Measurements of $E$. Coli and $\mathrm{BOD}_{5}$ in the effluent were done. Electrical conductivity (EC), total phosphorus, total nitrogen, total suspended solids, sodium, calcium and magnesium cations were also done in the irrigation water. Sodium Adsorption Ratio (SAR), Soluble Sodium Percentage (SSP) and Exchangeable Sodium Percentage (ESP) for the evaluation of the effluent effect on soil salinity were calculated using standard equations. The concentrations of the measured and calculated effluent parameters were compared with the World Health Organisation (WHO) and Food and Agriculture Organisation (FAO) guidelines for irrigation water quality. Generally the effluent was suitable for use in irrigation except for one abstraction point where the E. Coli levels were too high.

Keywords: treated wastewater effluent, irrigation, sodium adsorption ratio (SAR), soluble sodium percentage.
\end{abstract}

\section{Introduction}

The world is experiencing growing water stress. The water stress is due to increasing demand because of population growth, periodic droughts as a result of 
climate change and pollution from increasing volumes of wastewater discharged untreated or partially treated. The pressure for the available limited fresh water resources has grown to the extent that other unconventional sources of water are being exploited for various uses. Namibia is one of the driest countries in Southern Africa and is expected to become hotter and drier in future due to climate change (Reid et al. [1]). The country is characterized by mono seasonal rainfall with spatial variation from less than $50 \mathrm{~mm} /$ annum in the southwest and along the west coast to more than $600 \mathrm{~mm} /$ annum in the north eastern Caprivi strip (Mendelsohn et al. [2]). The rainfall is uncertain with long periods of severe droughts, frequently experienced (Lahnsteiner and Lempert [3]). The long term average annual precipitation for the central area is about $370 \mathrm{~mm} / \mathrm{yr}$ with a potential annual evapotranspiration in the range of 3,200-3,400 mm (Department of Water Affairs [4]). The city of Windhoek, located in the central area, has been successfully doing direct reclamation of treated domestic effluent to portable standards since 1968 (WINGOC [5]). About $30 \%$ of the reclaimed water is blended with fresh treated water and supplied to the Windhoek consumers. Windhoek's semi-arid conditions coupled with the increasing demand for fresh water have resulted in farmers opting to use partially treated effluent for irrigation purposes. Treated effluent is now widely used for agricultural irrigation particularly in arid regions of the world (Hamilton et al. [6]). The advantages of wastewater effluent re-use include reliable availability, especially in cities with centralised wastewater collection and treatment systems. Domestic wastewater effluent is rich in nutrients (phosphorus and nitrogen) hence its use for irrigation purpose reduces or eliminate the need for artificial fertilisers. Re-use of waste water also reduces the treatment cost for the effluent by reducing the need for advanced waste water treatment processes. Irrigation with treated municipal waste water is considered environmentally sound wastewater disposal practice. However there are two major hazards associated with waste water reuse namely; health risks from pathogens and environmental risks (Barker-Reid et al. [7]). Associated environmental risks include salinity, sodicity, nutrients, heavy metals and inorganic contaminants accumulation (WHO [8]).

The water quality is a guiding factor in the selection of irrigation method. The quality of the semi or partially treated wastewater effluent has not been evaluated in Windhoek though it is being used for vegetable irrigation. This raises concerns from the public on the risks of consuming vegetables irrigated with such water on human health and the environmental impact of using partially treated effluent. The main objective of this study was to determine the suitability of the semi-treated effluent for use in vegetable irrigation by evaluating its quality. The environmental impact was evaluated by determining the Sodium Adsorption Ratio (SAR) and Exchangeable Sodium Percentage (ESP) in the soil.

\section{Materials and methods}

\subsection{Study area}

Windhoek is situated in the central area of Namibia at latitudes $22^{\circ} 33^{\prime}$ South and longitude $17^{\circ} 4^{\prime}$ East with a mean altitude of $1,657 \mathrm{~m}$. The temperatures ranges 
from $-5^{\circ} \mathrm{C}$ to $18^{\circ} \mathrm{C}$ in winter and from $20^{\circ} \mathrm{C}$ to $31^{\circ} \mathrm{C}$ in summer. Rainfall is received in summer with a long term annual average of $370 \mathrm{~mm}$, which is too low and erratic to support crop and vegetable production without irrigation. The population of Windhoek is about 325,858 people which is about $39.5 \%$ increase from the 2001 population (Namibia Statistics Agency [9]).

The city of Windhoek has almost all the formal settlements connected to the sewerage network while some sections of informal settlements are still to be connected to the sewage system. There are separate sewerage treatment plants for industrial wastewater and domestic wastewater. The industrial wastewater production for Windhoek was about $0.3 \mathrm{Mm}^{3} /$ year (Lahnsteiner and Lempert [3]). The volume of domestic wastewater currently being produced from the city of Windhoek is estimated to be about $12 \mathrm{Mm}^{3} /$ year with the design capacity of the treatment plant being $27,000 \mathrm{~m}^{3} /$ day. The domestic wastewater goes through the conventional treatment processes of primary treatment, secondary treatment which incorporates activated - sludge process and attached growth process as shown on the flow chart in Figure 1. The effluent from the secondary treatment goes through a series of ponds for the final polishing before it is discharged into the Gorengab Dam while the other flow stream goes for reclamation. The final effluent quality should have a biochemical oxygen demand (BOD) of $<30 \mathrm{mg} / \mathrm{L}$, total suspended solids $<100 \mathrm{mg} / \mathrm{L}$, ammonia $<2.5 \mathrm{mg} / \mathrm{L}$ and chemical oxygen demand (COD) of $<35 \mathrm{mg} / \mathrm{L}$.

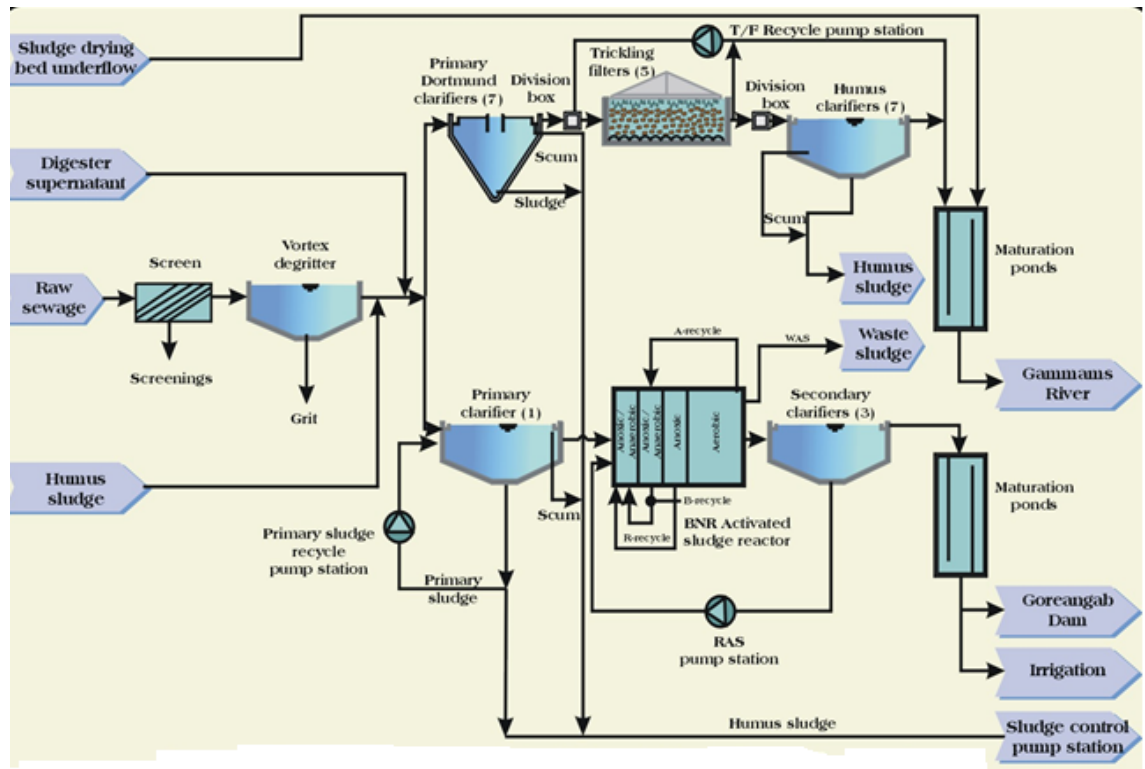

Figure 1: Process flow chart of the Windhoek Gammas Water Care Works: Adapted from City of Windhoek. 


\subsection{Sampling and water quality analysis}

Samples of treated and untreated wastewater effluent were collected weekly as grab samples for six weeks from August 2014 to September 2014. The samples were collected at the abstraction points for the pumps delivering water to the gardens as shown on Figure 2. A sension154 multimeter was used to measure electrical conductivity (EC), Temperature, $\mathrm{pH}$ and total dissolved solids in situ. Turbidity was measured on site using a turbidimeter 2100PY following the HACC standard procedure. Total suspended solids were measured in accordance with AWWA 2540D method (AWWA and APH [10]). BOD was measured in the laboratory using Hach standard method procedure. Nitrogen and phosphorus were measured using a H ODYSEY DR/2500 spectrophotometer. $\mathrm{Cd}$ and $\mathrm{Pb}$ in the effluent were measured using an ICP Device 3120D in accordance with the AWWA method. The conventional incubation and colony counter method was used for the determination of Escherichia Coli (E. Coli).

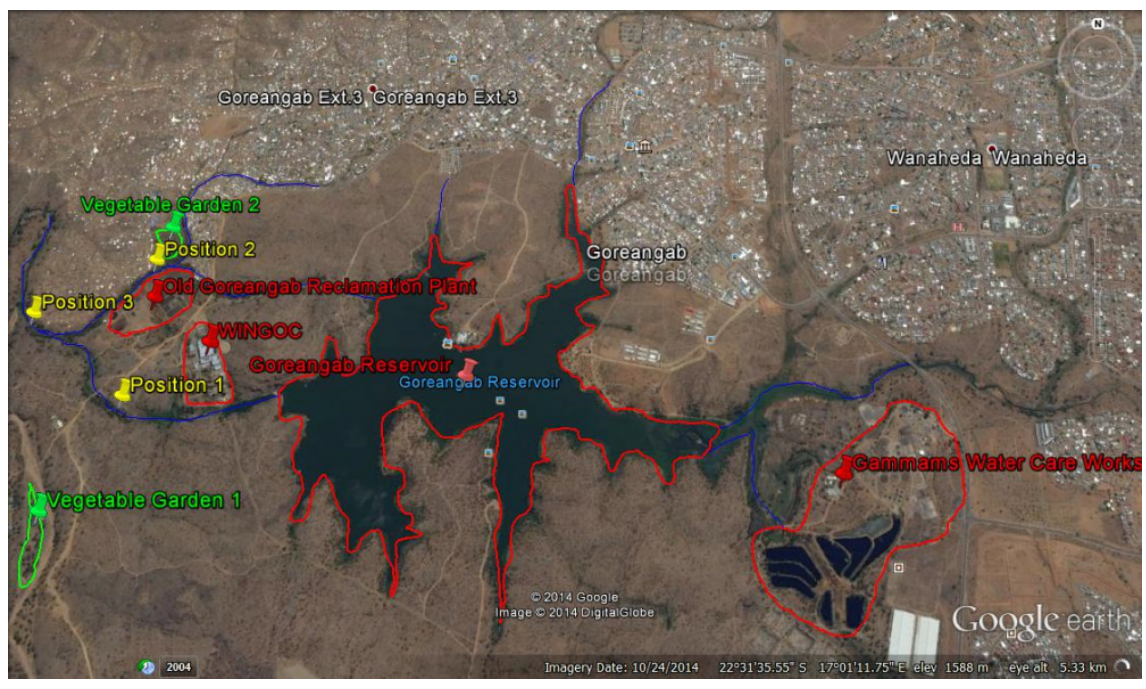

Figure 2: Map showing the positions of the gardens and the sampling positions 1,2 and 3.

\section{Results and discussion}

A summary of the results of the effluent analysis of the physical, chemical and bacteriological quality is presented in Table 1.

\subsection{Vegetables}

The major vegetables being grown by the farmers using the untreated and treated wastewater effluent are spinach, spring onions and carrots which are grown under sprinkler irrigation. 


\subsection{Electrical Conductivity (EC)}

The (EC) which measures the salinity hazard ranged between $120.4 \mathrm{mS} / \mathrm{s}$ to 151.2 $\mathrm{mS} / \mathrm{s}$ for the three sampling positions with an averages of 127.9, 123.6 and 123.6 $\mathrm{mS} / \mathrm{m}$ for position 1,2 and 3 respectively. The FAO guidelines recommended a maximum of $300 \mathrm{mS} / \mathrm{m}$ for irrigation water (Ayers and Westcot [11]). EC is an indicator of the total dissolved solids in the water. An EC of $160 \mathrm{mS} / \mathrm{m}$ falls in the high category according to the US Salinity Laboratory, 1954 classification. The level of EC indicates that salinity conditions will develop unless leaching and drainage are adequate in the soil. Since the ECs measured at the three positions were less than the $160 \mathrm{mS} / \mathrm{m}$ therefore the effluent was suitable for irrigation with respect to salinity problems.

\section{3 pH}

The in situ $\mathrm{pH}$ values for the effluent varied between 3.9-6.1 with an average value of 4.5 for all the positions 1, 2 and 3. The FAO irrigation water guidelines and South African guidelines recommend a $\mathrm{pH}$ range of 6.5-8.4 for irrigation water. The $\mathrm{pH}$ of the effluent is acidic for the direct reuse of the effluent for irrigation purposes without pre-treatment of the effluent or soil treatment. A pH of less than 6.5 promotes leaching while a $\mathrm{pH}$ greater than 11 inhibits movement of heavy metals through the soil (Mutengu et al. [12]).

\subsection{Turbidity}

The turbidity ranged from 6 to 15 NTU with averages 10.7, 11 and 12.7 NTU at the positions 1, 2 and 3 respectively. The turbidity is higher than the FAO recommended turbidity of 5 NTU. High turbidity may result in the effluent harbouring disease causing microorganisms exposing effluent users to diseases (Hoko [13]).

\subsection{Total Dissolved Solids (TDS)}

The TDS in the effluent ranged from 637-985 mg/L during the sampling period with an average of $811 \mathrm{mg} / \mathrm{L}$. Effluent with TDS in the range 450-2000 mg/L can be moderately used for irrigation. Excessive levels of TDS $>2000 \mathrm{mg} / \mathrm{L}$ will result in build-up of salts in the root zone altering the soil properties and reducing the yields. Windhoek's effluent is suitable for irrigation reuse but monitoring for build-up of salts in the soil is required.

\subsection{Cadmium and lead}

The cadmium and lead concentration of the effluent were found to be $<0.01 \mathrm{mg} / \mathrm{L}$ for all the sampling points which is satisfactory for the use of the effluent for irrigation. The FAO and South African guidelines both set the maximum allowable concentration of cadmium and lead in irrigation water at $0.01 \mathrm{mg} / \mathrm{L}$ and $5.0 \mathrm{mg} / \mathrm{L}$ respectively. Cadmium has the potential to accumulate in plants and soils resulting in toxicity to humans and animals. Lead results in yield reduction and crop failure. 


\subsection{Quality of effluent}

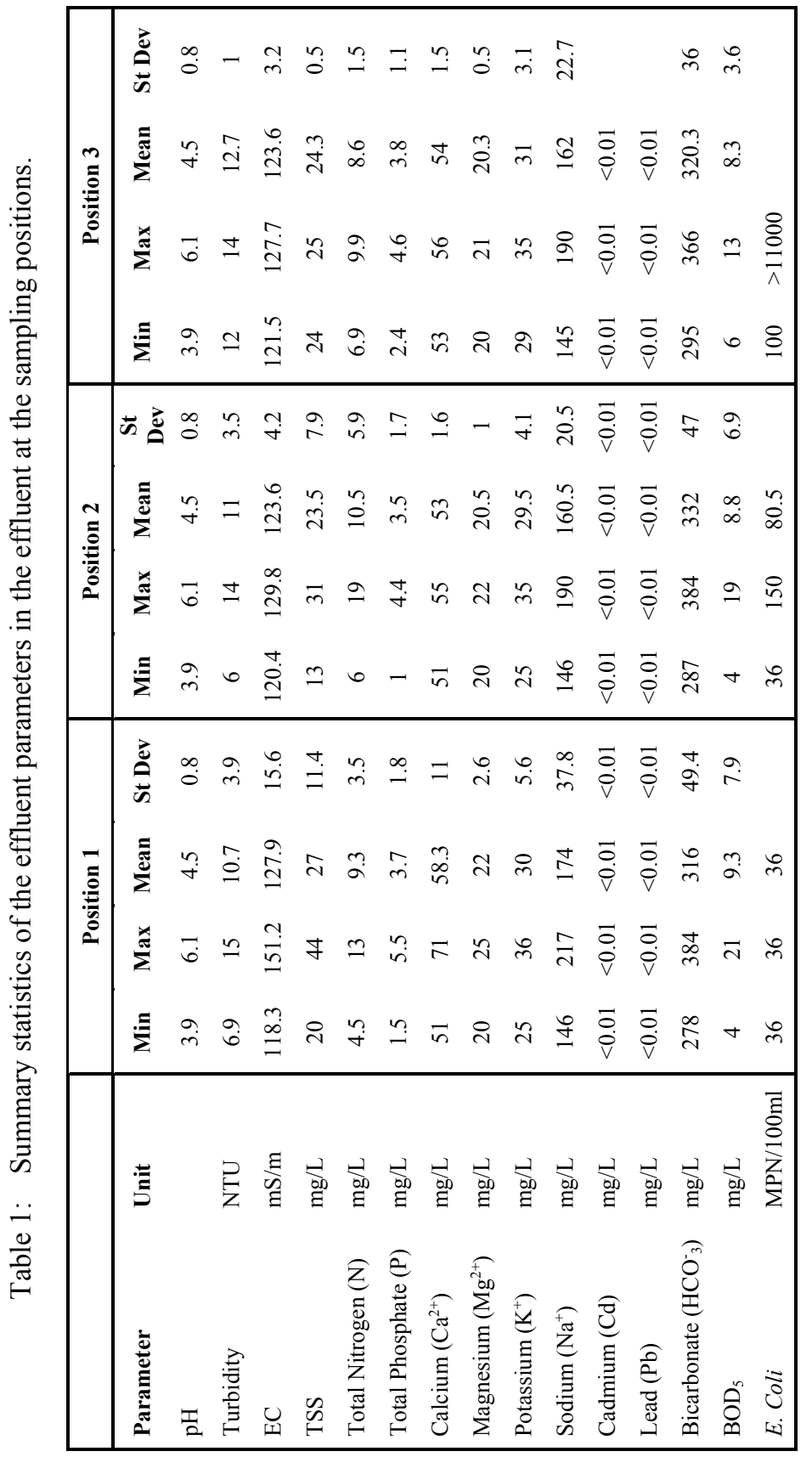


The low levels of cadmium and lead in the effluent are probably because the effluent is from domestic sources. The city of Windhoek separates the domestic wastewater from the industrial wastewater and they are treated at different wastewater treatment plants.

\subsection{Total nitrogen}

Total nitrogen (TN) refers to all the forms of nitrogen which can be found in effluent as ammonia, nitrate, organic nitrogen and nitrite. The TN in the effluent ranged from $4.5-19 \mathrm{mg} / \mathrm{L}$ with an average of $10 \mathrm{mg} / \mathrm{L}$. The variation of the TN during the sampling weeks is shown in Figure 3. About $50 \%$ of the ammonia and $30 \%$ of the organic nitrogen are assimilated by plants with the rest being lost during transformation (WHO [8], Girovich [15]) and most nitrates are washed out. Total nitrogen concentration of less than $5 \mathrm{mg} / \mathrm{L}$ does not affect most crops while $\mathrm{TN}$ concentrations $>30 \mathrm{mg} / \mathrm{L}$ is severe, however nitrogen requirements depends on the crop level of development. With respect to TN the effluent was suitable for irrigation since it was found to be less than $30 \mathrm{mg} / \mathrm{L}$. Nitrates maybe leached down to the groundwater sources where they can contaminate the drinking water and pose health threats to consumers (WHO [8]). The relatively higher levels of nitrogen in the effluent may also result in overstimulation of growth of algae and aquatic plants.

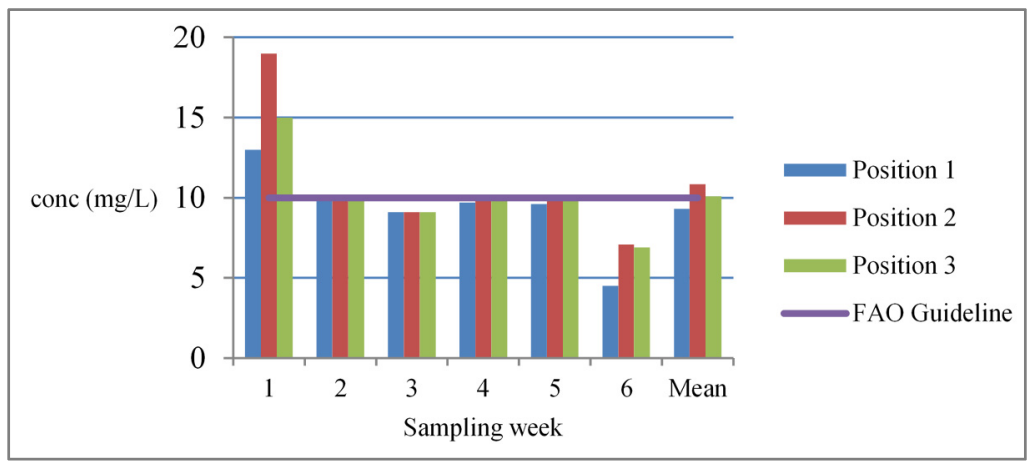

Figure 3: Total nitrogen as $\mathrm{N}$ concentration in the effluent.

\subsection{Total phosphate}

The total phosphate in the effluent ranged from $1.0-5.5 \mathrm{mg} / \mathrm{L}$ with an average of $3.7 \mathrm{mg} / \mathrm{L}$ as shown in Figure 4. Phosphorous is often scarce in the soil and is supplied to plants as an artificial fertilizer. Availability of phosphorus in the effluent could be beneficial for the vegetables. Ayers and Westcot [11] recommended a maximum phosphorus level of $2 \mathrm{mg} / \mathrm{L}$. The treated effluent had phosphorus levels above the maximum recommended level; hence environmental damage may be caused. The use of the effluent for irrigation may help in recycling the phosphorus and minimize environmental damage thereby reducing eutrophication of water bodies receiving Windhoek's effluent. 


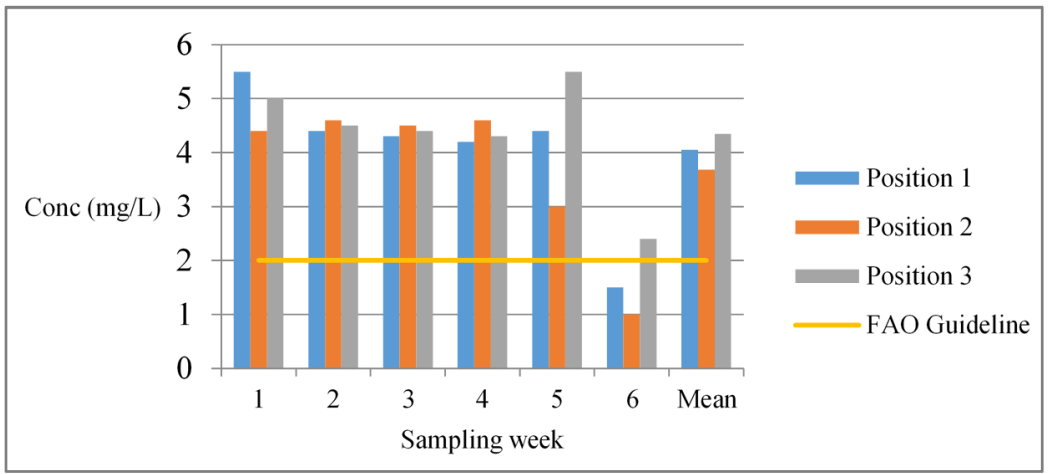

Figure 4: Total phosphate as P concentration in the effluent.

\subsection{Potassium}

The potassium levels in the effluent were as shown in Figure 5. The levels were well above the recommended FAO limit for irrigation water effluent of $2 \mathrm{mg} / \mathrm{L}$, which may have a negative impact on the level of eutrophication that can occur in the receiving water bodies (WHO [8]).

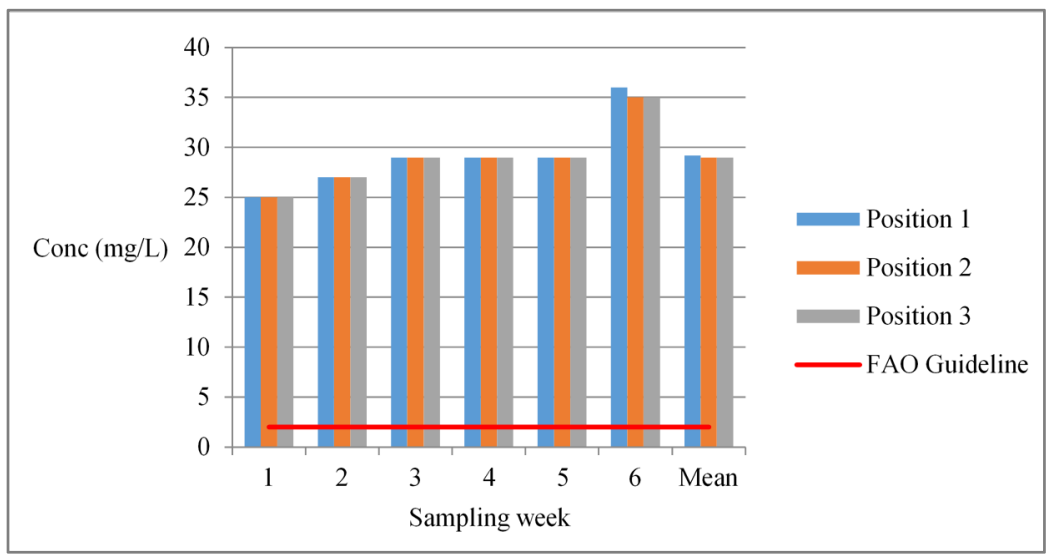

Figure 5: Potassium as $\mathrm{K}$ concentration in the effluent.

\subsection{Sodium hazard}

The sodium hazard is expressed in terms of the Sodium Adsorption Ratio (SAR). SAR is measure of the ratio of sodium ions to calcium and magnesium ions in the soil. It is calculated using equation (1).

$$
S A R=\frac{N a^{+}}{\sqrt{\frac{C a^{2+}+M g^{2+}}{2}}}
$$


where the ionic concentrations of $\mathrm{Na}, \mathrm{Ca}$ and $\mathrm{Mg}$ expressed in meq/L.

The SAR of the treated effluent ranged from 4.31 to 5.64 as shown in Table 2 below. The SAR is below 15, the threshold where problems of water absorption by plants occur (Ayers and Westcot [11]). Irrigation water with a higher SAR results in build-up of sodium levels in the soil. The effects of the sodium build up are soil crusting, poor seedling emergence (Lesch and Suarez [17]). A high SAR also reduces soil infiltration and percolation due to dispersion of the fine particles like clay clogging the pore spaces. Excessive sodium also impairs water infiltration (Pescod [16]). The effluent has sodium ion content in the range of 6.31$9.44 \mathrm{meq} / \mathrm{L}$. A high concentration of sodium ions can cause leaf damage to crops especially when used with sprinkler irrigation in high temperature and low humidity climates (Ayers and Westcot [11]). Effluent with $>9$ meq/L of sodium has a severe restriction to use for irrigation purposes. Therefore selection of appropriate irrigation systems, monitoring of effluent SAR quality and management of irrigation systems are required for mitigation of possible sodium problems in the reuse of Windhoek's effluent.

Table 2: Calculated wastewater effluent characteristics.

\begin{tabular}{|l|cc|cc|cc|}
\hline & \multicolumn{2}{|c|}{ Position 1 } & \multicolumn{2}{c|}{ Position 2 } & \multicolumn{2}{c|}{ Position 3 } \\
\hline Characteristic & Min & Max & Min & Max & Min & Max \\
\hline SAR & 4.39 & 5.64 & 4.39 & 5.48 & 4.31 & 5.50 \\
SSP & 55.85 & 58.14 & 55.85 & 59.11 & 54.56 & 59.25 \\
ESP & 4.95 & 6.59 & 4.95 & 6.38 & 4.85 & 6.41 \\
\hline
\end{tabular}

\subsection{Soluble sodium percentage}

SSP is also used to evaluate sodium hazard and is calculated using equation (2).

$$
S S P=\frac{\left(N a^{+}\right) \times 100}{C a^{2+}+M g^{2+}+N a^{+}+K^{+}}
$$

The SSP for the effluent ranges between 54\% and 59\% as shown in Table 2 above. The quality of the effluent indicates moderate degree of restriction for use in irrigation. A SSP of more than $60 \%$ may result in sodium accumulation on soil colloids causing breakdown of the soil's physical properties. The degree of absorption of sodium ions to clay particles depends on their concentration in the water and the concentration of calcium and magnesium ions. Agronomic and/or effluent treatment practices that increase potassium, calcium and/or magnesium ions in the soil or water may be appropriate for Windhoek's effluent. The exchangeable sodium percentage (ESP) measures the crop tolerance to sodium.

\subsection{Biochemical oxygen demand}

The BOD of the effluent had averages of $9.3,8.8$ and $8.3 \mathrm{mg} / \mathrm{L}$ for positions 1,2 and 3 respectively. The FAO guideline recommends a maximum level of $10 \mathrm{mg} / \mathrm{L}$ for the BOD. The effluent quality is acceptable for irrigation in terms of BOD. 


\subsection{Effluent bacteriological quality}

E. Coli was measured at the three sampling positions and the levels ranged from 36 to $>11,000 \mathrm{MPN} / 100 \mathrm{ml}$ as shown in Table 1.The $E$. Coli levels increased from position 1 to 3 along the streams. The FAO guideline indicates a level of less than $1 \mathrm{MPN} / 100 \mathrm{~mL}$ as completely safe for use for irrigation of vegetables eaten raw or uncooked. An E. Coli level of 1-1,000 MPN/100 mL is recommended for use on vegetables which are consumed after cooking. Water containing more than 1,000 $\mathrm{MPN} / 100 \mathrm{~mL}$ is unsafe for irrigation. For sampling position 1 and 2 the E. Coli levels were found to be less than 1,000 MPN/100 mL. This made the effluent suitable for use for irrigation of vegetables which were not likely to be eaten raw. Position 3 had high E. Coli levels ranging from 4,600 to 11,000 MPN/100 mL. The high level was attributed to the lack of conventional sanitation facilities in the informal settlement located on the right banks of the river and downstream of position 2 . The farm workers are likely to be exposed to pathogens as they use the effluent for irrigation (Faruqui et al. [18]).

\section{Conclusion and recommendations}

The physical and chemical analysis of the treated domestic effluent from the Gammams wastewater treatment plant showed that the effluent is generally suitable for use in vegetable irrigation. The high levels of macro nutrients $\mathrm{N}, \mathrm{P}$ and $\mathrm{K}$ in the effluent provided the essential nutrients for plant growth which can reduce amount of input fertilisers, and the uptake of the macro nutrients by plants may reduce environmental pollution. The low levels of $<0.01 \mathrm{mg} / \mathrm{L}$ of cadmium and lead meant that the effluent had low risks of causing heavy metal accumulation in the vegetables and the soil, therefore the effluent was safe for irrigation of the vegetables if water was abstracted at positions 1 and 2 . The effluent from position 3 and downstream reaches could cause a health risk to farm workers due to possible exposure to high levels of pathogens in the effluent. The effluent from position 3 could be used with irrigation systems that prevent contact between the effluent and crops, or for the production of other above ground crops whose leaves are not eaten raw such as dry maize.

Windhoek's treated effluent is always available even during the dry season so it can be a useful resource for food production and not regarded as a waste. With careful monitoring of water and soil quality parameters, like SAR, SSP, electrical conductivity, $\mathrm{pH}, E$. Coli and macro nutrients, the effluent can be suitable source of water for irrigation purposes.

\section{Acknowledgement}

The researchers would like to thank the Polytechnic of Namibia IRPC for funding the research. 


\section{References}

[1] Reid, H., Sahlén, L., Stage, J., MacGregor, J. The economic impact of climate change in Namibia: How climate change will affect the contribution of Namibia's natural resources to its economy. Environmental Economics Programme Discussion Paper 07-02. International Institute for Environment and Development, London, pp. 7-9, 2007.

[2] Mendelsohn, J., Jarvis, A., Roberts, C., and Robertson, T. Atlas of Namibia: a portrait of the land and its people: David Philip Publishers, Cape Town, 2002.

[3] Lahnsteiner, J., Lempert, G., Water management in Windhoek, Namibia. Water Science and Technology, 55(1), pp. 441-481, IWA Publishing, 2007.

[4] Department of Water Affairs, Evaporation map for Namibia, Report No.11/18/H1, p. 1, 1988.

[5] WINGOC, www.wingoc.com.na/history.html

[6] Hamilton, A.J., Stangnitti, F., Xiong, X., Kreidl, S.L., Benke, K.K., Maher, P. Wastewater irrigation: the state of play. Vadose zone, 6(4), pp. 823-840, 2007.

[7] Barker-Reid, F., Harper, G.A., Hamilton, A.J., Affluent effluent: growing vegetables with wastewater in Melbourne, Australia-a wealthy but bone-dry city, 2009.

[8] WHO, Guidelines for the safe use of wastewater, excreta and grey water. Volume II, wastewater use in Agriculture. Geneva, World Health Organisation, pp. 107-128, 2006.

[9] Namibia Statistics Agency, Namibia Population and Housing Census Report, p. 39, 2011, www.nsa.org.na

[10] AWWA and APH, (22 ${ }^{\text {nd }}$ eds). Standard Method for the Examination of Water and Wastewater. American Water works, 2012.

[11] Ayers R.S., Westcot D.W., Water Quality for Agriculture. Rome, Food and Agriculture Organisation of the United Nations (FAO Irrigation and Drainage paper 29, 1985.

[12] Mutengu, S., Hoko, Z., Makoni, F.S., An Assessment of the public health hazard potential of wastewater reuse for crop production. A case of Bulawayo city, Zimbabwe. Physics and Chemistry of the earth, (32), pp. 1195-1203, 2007.

[13] Hoko, Z., 2005. An Assessment of water quality of drinking water in rural districts in Zimbabwe the case of Gokwe South, Nkayi, Lupane and Mwenezi districts. Physics and Chemistry of the earth, (30), pp. 859-866, 2005.

[14] WHO, Cadmium-environmental aspects. Geneva, World Health Organisation, Environmental Health Criteria, 1992.

[15] Girovich, M. J., Bio solids treatment and management: processes for beneficial use. Environmental Science and pollution control, (18), 1996.

[16] Pescod, M.B., Wastewater Treatment and use in Agriculture. FAO of the United Nations, Rome, FAO Irrigation Drainage Paper 47, 1992. 
[17] Lesch. S.M and Suarez D.L, A short note on calculating the adjusted SAR index, American Society of Agricultural and Biological Engineers, 52(2), pp. 493-549, 2009.

[18] Faruqui, N., Scott, C., \& Raschid-Sally, L., Confronting the Realities of Wastewater Use in Irrigated Agriculture: Lessons Learned and Recommendations. Ottawa: CABI Publishing, 2004. 